\title{
Molecular Characterization and Genetic Analysis of Pseudomonas Aeruginosa Recovered from Broiler Chickens
}

1 *Soha S. El-Sadda, ${ }^{1}$ Es awy, A. I., ${ }^{2}$ Reham M. El-Tarabili and ${ }^{2}$ Khafagy, A. R.

${ }^{1}$ Animal Health Research Institute, Mansoura branch

${ }^{2}$ Bacteriology, Immunology and Mycology Department, Faculty of Veterinary Medicine, Suez Canal University

*Corresponding author: Soha S. El-Sadda (Sohasami97@yahoo.com)

\begin{abstract}
:
Pseudomonas aeruginosa is an opportunistic pathogen causes serious problems in broiler farms and this pathogen has an economical importance in broiler sector. A total of 200 broiler chickens of different ages [84 broiler chicks (1-7 days) and 116 broiler chickens (1-6 weeks)] were collected from different broilers farms for isolation and identification of $P$. aeruginosa. Different samples were taken from internal organs (liver, gall bladder, lung, heart blood, intestine, kidney, yolk sacs) as well as cloacal swabs. The samples were examined bacteriologically, 28 isolates $(14 \%)$ of $P$. aeruginosa were isolated and identified by biochemical reactions as well as API $20 \mathrm{E}$ system. The yolk sac and cloacal swabs samples gave the highest recovery rates with percentages of $15.5 \%$ and $12.6 \%$, respectively. PCR assay confirmed the existence of $P$. aeruginosa DNA in ten isolates by using 16S rRNA gene. Also, PCR assay was carried out to detect the presence of virulence genes as $o p r \mathrm{~L}$, tox $\mathrm{A}$ and $a p r \mathrm{~A}$. The $o p r \mathrm{~L}$ gene was present with a percentage of $100 \%$, toxA was present with a percentage of $80 \%$, and aprA gene with a percentage of $40 \%$. Also, sequencing of $16 \mathrm{~S}$ rRNA gene of $P$. aeruginosa was submitted to Gen Bank with accession number MW051028 which was $100 \%$ identical to $P$. aeruginosa strains.
\end{abstract}

Keywords: $P$. aeruginosa, chickens, virulence genes, PCR, 16S rRNA gene sequence.

\section{Introduction:}

Pseudomonas species found everywhere and are isolated from various sources such as drinking water, domestic and wild animals, human beings, plants, and from a variety of foods. These Gram-negative bacteria are non-fermentative rods, aerobic, oxidase-positive 
and motile with polar flagella (Arnaut-Rollier et al., 1999; Jay et al., 2005; Franzetti and Scarpellini, 2007 and Adams and Moss, 2008). Pseudomonas infections of birds are of a great importance as epidemics may spread rapidly through the poultry flocks causing mortality in all ages (Satish and Priti, 2015). $P$. aeruginosa is an opportunistic pathogen capable of infecting all tissues (Van Delden and Iglewski, 1998 and Khattab et al., 2015). It is always classified as the head most of three frequent Gram-negative pathogens and is associated with the worst visual diseases. Its outbreak varies from 2 to $100 \%$ (Fick, 1993; Barnes, 1997 and Saad et al., 2017). P. aeruginosa has a variety of virulence factors that frustrate host defenses and make direct tissue's harm or rise bacterium's affordability. The most important virulence factors of $P$. aeruginosa includes Exotoxin A (eta), outer membrane associated protein $\mathrm{L}$ and I and quorum-sensing determinant system (Gellatly and Hancock, 2013). Exotoxin A (eta) is a strong extracellular virulence factor produced by most of clinical isolates of $P$. aeruginosa (Salman, 2015). The $\operatorname{apr} \mathrm{A}$ is one of the most important virulence factors of $P$. aeruginosa which is a zincdependent metalloprotease (Hoge et al., 2010). Polymerase chain reaction (PCR) is one of the notable methods for detection and identification of $P$. aeruginosa (Deschaght et al., 2011). It has the potential for identifying microbial species rapidly by amplification of sequences unique to a particular organism that is outer lipoprotein membrane (oprL) gene in $P$. aeruginosa isolates (Khan and Cerniglia, 1994). Sequencing of $16 \mathrm{~S}$ rDNA gene is specifically important in the case of bacteria with unusual phenotypic profiles, rare bacteria, slow growing bacteria, uncultivable bacteria and culture-negative infections. Not only has it provided insights into etiologies of infectious disease, but it also helps in choosing antibiotics and in determining the duration of treatment and infection control procedures (Woo et al., 2008). Identification of bacteria at species level, DNA sequences at genus-specific might be widely used. Therefore, the present study was planned for bacteriological characterization of $P$. aeruginosa isolated from broiler chickens with different ages, detection of virulence genes as well as sequencing of $16 \mathrm{~S}$ rRNA gene and submission into Gen Bank.

\section{Mate rial and Methods:}

\section{Samples collection}

A total of 200 chickens of different ages [84 broiler chicks 
(1-7 days) and 116 broiler chickens (1-6 weeks)] were collected from different broilers farms in Suez Canal area for isolation and identification of $P$. aeruginosa. The samples were collected from 51 apparent healthy broiler chickens, 84 diseased broiler chickens showing (profuse diarrhea and respiratory manifestations including coughing, sneezing, rolling, nasal discharges) and 65 freshly dead broiler chickens as shown in Table (1). The samples were collected from internal organs: 200 for each (liver, gall bladder, lung, heart blood, intestine, kidney), 135 cloacal swabs and 84 yolk sacs of chicks. All samples were handled aseptically to prevent crosscontamination using sterile sampling materials and transferred immediately in ice box to the laboratory.

\section{Isolation and Identification}

The samples were inoculated in nutrient broth and incubated aerobically for $24 \mathrm{hrs}$ at $37^{\circ} \mathrm{C}$. Then a loopful of the inoculated nutrient broth was streaked onto selective media (Pseudomonas agar base) and incubated aerobically for $24 \mathrm{hrs}$ at $37^{\circ} \mathrm{C}$. The suspected colonies were inoculated for $24 \mathrm{hrs}$ at $37^{\circ} \mathrm{C}$ onto nutrient agar, sheep blood agar and MacConkey agar. The characteristic colonies of $P$. aeruginosa were selected and the Gram staining was performed.
The colonies showing typical colonial appearance were subjected to biochemical identification and examined for Catalase, Oxidase, Urea hydrolysis, Indole, Methyl red, Citrate utilization, VogesProskauer and Hydrogen Sulphide production tests described by Quinn et al. (2002). Also, API 20E (BioMérieux ${ }^{\circledR}$, France) was used as a confirmatory biochemical test.

Molecular detection of $\mathbf{1 6 S}$ rRNA gene, virulence genes as $o p r \mathrm{~L}$, tox A, aprA of $P$. aeruginosa is olates by PCR

Conventional PCR assay for confirmation of $P$. aeruginosa isolates and detection of virulence genes was performed. DNA was extracted from the isolated $P$. aeruginosa using QIAamp DNA mini kit (Germany). PCR Master Mix and cycling conditions of the primers during PCR were prepared according to Emerald Amp GT PCR master mix (Takara) Code No. RR310A kit. Oligonucleotide primers used in PCR have specific sequence and amplify a specific product as shown in Table (2). DNA samples were amplified in a total of $25 \mu 1$ as follows: $12.5 \mu \mathrm{l}$ of Emerald Amp GT PCR Master Mix, $1 \mu \mathrm{l}$ of each primer of 20 pmol concentrations, $4.5 \mu \mathrm{l}$ of water, and $6 \mu$ of template DNA. The reaction was performed in a Biometra thermal cycler (Bio- 
Rad S1000 USA). Temperature and time conditions of the primers during PCR were applied (Table, 2). Aliquots of amplified PCR products were electrophoresed in 1.5\% agarose gel (ABgene) in 1x TBE buffer at room temperature. For gel analysis, $15 \mu \mathrm{l}$ of PCR products were loaded in each gel slot. A 100 bp DNA Ladder (QIAGEN Inc, Valencia, CA, USA) was used to determine the fragment sizes. The gel was photographed by a gel documentation system and the data was analyzed through computer software.

Gene Sequencing

PCR products were purified using QIA quick PCR Product extraction kit (QIAGEN Inc, Valencia, CA, and USA). Big dye Terminator v3.1 cycle sequencing kit. (PerkinElmer/Applied Biosystems, Foster City, CA) was used for the sequence reaction and then it was purified using Centrisep (spin column). DNA sequences were obtained by Applied Biosystems 3130 genetic analyzer (HITACHI, Japan) and a comparative analysis of sequences was performed using CLUSTAL W. multiple sequence alignment program, version 1.83 of Meg Align module of Laser gene DNA Star software.

\section{Statistical analysis}

The Chi-square test and $\mathrm{P}$ value were performed to analyze the obtained results (SPSS software, version 22) (significance level; $P$ $<0.05$ ) according to Greenwood and Nikulin (1996).

Table (1): Number and type of examined samples

\begin{tabular}{|c|c|c|c|c|}
\hline Source of sample & Apparent healthy & Diseased & Freshly dead & Total \\
\hline $\begin{array}{c}\text { Broiler chicks } \\
\text { (1-7 days) }\end{array}$ & 12 & 44 & 28 & 84 \\
\hline $\begin{array}{c}\text { Broiler chickens } \\
\text { (1-6 weeks) }\end{array}$ & 39 & 40 & 37 & 116 \\
\hline Total & 51 & 84 & 65 & 200 \\
\hline
\end{tabular}


Table (2): Oligonucleotide primers for 16S rRNA and virulence genes of $P$. aeruginosa, the size of amplified products, and cycling conditions required for detecting the tested genes

\begin{tabular}{|c|c|c|c|c|}
\hline $\begin{array}{l}\text { Target } \\
\text { gene }\end{array}$ & Primer sequence $\left(5^{\prime}-3{ }^{\prime}\right)$ & $\begin{array}{l}\text { Amplicon size } \\
\text { (bp) }\end{array}$ & $\begin{array}{l}\text { Cycling conditions } \\
\text { (All genes involved } \\
\text { initial denaturation at } \\
95^{\circ} \mathrm{C} \text { for } 2 \text { min. } \\
\text { followed by } 35 \text { cycles) }\end{array}$ & Reference \\
\hline $\begin{array}{l}\text { 16S } \\
\text { rRNA }\end{array}$ & $\begin{array}{c}\text { GGGGGATCTTCGG } \\
\text { ACCTCA } \\
\text { TCCTTAGAGTGCC } \\
\text { CACCCG }\end{array}$ & 956 & $\begin{array}{c}\text { Denaturation: } 94^{\circ} \mathrm{C} / 20 \\
\text { sec; Annealing: } \\
58^{\circ} \mathrm{C} / 20 \mathrm{sec} \text {; Extension: } \\
72^{\circ} \mathrm{C} / 40 \mathrm{sec} ; \\
\text { Final extension: } 72^{\circ} \mathrm{C} / 1 \\
\text { min } \\
\end{array}$ & $\begin{array}{l}\text { Spilker et } \\
\text { al., } 2004\end{array}$ \\
\hline oprL & $\begin{array}{c}\text { ATG GAA ATG CTG } \\
\text { AAA TTC GGC } \\
\text { CTT CTT CAG CTC } \\
\text { GAC GCG ACG }\end{array}$ & 504 & $\begin{array}{c}\text { Denaturation: } 96^{\circ} \mathrm{C} / 1 \\
\text { min; Annealing: } 55^{\circ} \mathrm{C} / 1 \\
\text { min; Extension: } 72^{\circ} \mathrm{C} / 1 \\
\text { min; } \\
\text { Final extension: } \\
72^{\circ} \mathrm{C} / 10 \text { min }\end{array}$ & $\begin{array}{c}\text { Xи et } \\
\text { al., } 2004\end{array}$ \\
\hline $\operatorname{tox} \mathrm{A}$ & $\begin{array}{c}\text { GGAGCGCAACT AT } \\
\text { CCCACT } \\
\text { TGGT AGCCGACGA } \\
\text { ACACATA }\end{array}$ & 150 & $\begin{array}{c}\text { Denaturation: } 95^{\circ} \mathrm{C} / 40 \\
\text { sec; Annealing: } \\
50^{\circ} \mathrm{C} / 1 \mathrm{~min} ; \\
\text { Extension: } 72^{\circ} \mathrm{C} / 2 \\
\text { min; } \\
\text { Final extension: } \\
72^{\circ} \mathrm{C} / 10 \mathrm{~min} \\
\end{array}$ & \multirow[b]{2}{*}{$\begin{array}{l}\text { Sabharwal } \\
\text { et al., } 2014\end{array}$} \\
\hline aprA & $\begin{array}{l}\text { GTCGACCAGGCGG } \\
\text { CGGAGCAGAT A } \\
\text { GCCGAGGCCGCCG } \\
\text { TAGAGGATGTC }\end{array}$ & 993 & $\begin{array}{c}\text { Denaturation: } 95^{\circ} \mathrm{C} / 40 \\
\text { sec; Annealing: } \\
65^{\circ} \mathrm{C} / 1 \mathrm{~min} ; \\
\text { Extension: } 72^{\circ} \mathrm{C} / 2 \\
\text { min; } \\
\text { Final extension: } \\
72^{\circ} \mathrm{C} / 10 \mathrm{~min} \\
\end{array}$ & \\
\hline
\end{tabular}

\section{Results:}

\section{Morphological} biochemical ide ntification of $P$. aeruginosa is olates

The colonies of $P$. aeruginosa appeared variable in size with blue-green or brown pigment on Pseudomonas agar base medium. On nutrient agar medium, the colonies were large, flat, spreading and irregular with grayish green or brown pigment on the culture with fruity grapelike odour. On blood agar medium, the colonies were surrounded by a wide zone of complete hemolysis

(Beta hemolysis). On MacConkey agar medium, large pale colonies were seen with greenish or brown pigment. $P$. aeruginosa isolates appeared to be Gram negative straight or slightly curved rods occurred singly, in pairs or in short chains, nonsporulated and non-capsulated. All isolates showed similar pattern of reaction despite of the source of sampling, it showed positive reaction to Catalase, Oxidase, Citrate and Urea hydrolysis tests while, negative reaction to Methyl red, VogesProskauer, Indole and $\mathrm{H}_{2} \mathrm{~S}$ 
production tests. Results of API 20E revealed the probability for $P$. aeruginosa as shown in Fig. (1).

Prevalence of $P$. aeruginosa in broiler chickens

$P$. aeruginosa was recovered in 28 out of 200 examined chickens with an incidence of $14 \%$. $P$. aeruginosa was isolated from apparently healthy chickens with a rate of $2(3.9 \%)$, diseased 20 (23. 8\%) and freshly dead 6 $(9.2 \%)$. Statistically, there is non-significant difference among the prevalence of $P$. aeruginosa in healthy, diseased and dead chickens. The total number of $P$. aeruginosa isolated from 84 broiler chicks (1-7 days) were 19 with an incidence of $22.6 \%$, and the total number of P. aeruginosa isolated from 116 broiler chickens (1-6 weeks) were 9 with an incidence of $7.8 \%$ as shown in Table (3). Statistically, there is a significant difference among the prevalence of $P$. aeruginosa in broiler chickens while broiler chicks show non-significant. According to the site of sampling, $P$. aeruginosa was isolated as the following: $4.5 \%$ (9 out of 200) from liver; $0.5 \%$ (1 out of 200) from lung; $1.5 \%$ (3 out of 200) from heart blood; $2.5 \%$ (5 out of 200) from intestine; $15.5 \%(13$ out of 84) from yolk sac; $12.6 \%$ (17 out of 135) from cloacal swab, and zero from gall bladder and kidney. Statistically, there is a significant difference among the prevalence of $P$. aeruginosa according to the site of sampling. Molecular confirmation of $P$. aeruginosa DNA by using $16 S$ rRNA gene

Ten $P$. aeruginosa isolates were subjected for molecular examination. PCR results confirmed the existence of $P$. aeruginosa DNA in the ten isolates by using $16 \mathrm{~S}$ rRNA gene at $956 \mathrm{bp}$ with a total percentage of $100 \%$ as shown in Fig. (2).

Molecular detection of virulence genes in $P$. aeruginosa is olates by PCR

All ten $P$. aeruginosa isolates confirmed by $16 \mathrm{~S}$ rRNA were tested for detection of virulence genes. The results showed that $o p r L$ gene was detected in all $P$. aeruginosa isolates with a percentage of $100 \%$ (Fig. 3). Also toxA was detected with the percentage $80 \%$ (Fig. 4). While aprA gene was detected with a percentage of $40 \%$ (Fig. 5).

Sequence analysis of $16 \mathrm{~S}$ rRNA gene of $P$. aeruginosa

The 16S rRNA gene sequence in this study had the accession number (MW051028) in GenBank. The nucleotide sequence analysis of (956 bp) PCR product representing the 16S rRNA gene of $P$. aeruginosa isolate in this study revealed identity $(100 \%)$ to various strains of poultry origin as $P$. aeruginosa S-04 16S rRNA gene (MT626658.1) (South Africa); 
plant origin as $P$. aeruginosa $23 \mathrm{~S}$ rRNA gene (MT544458.1) (India), $P$. aeruginosa AM02 16S rRNA gene (MT598016.1) (Indonesia), $\quad P$. aeruginosa AM14 16S rRNA gene (MT598018.1) (Indonesia), $P$. aeruginosa AJ18 16S rRNA gene (MT598021.1) (Indonesia), P.aeruginosa AP04 16SrRNA gene (MT598022.1) (Indonesia), P.aeruginosa AP17 16SrRNA gene (MT598024.1) (Indonesia) and $P$. aeruginosa $\mathrm{AB} 18 \quad 16 \mathrm{~S}$ rRNA gene (MT598026.1) (Indonesia); different origins as $P$. aeruginosa OIS 4.8.1 $16 \mathrm{~S}$ rRNA gene (MT633047.1) (Russia), $\quad P$. aeruginosa MLTBM2 16S rRNA gene (MT646431.1) (Republic of the Congo), $\quad P$. aeruginosa NC110620 16S rRNA gene (MT623377.1) (India) and $P$. aeruginosa A-7 16S rRNA gene (MT573199.1) (China).

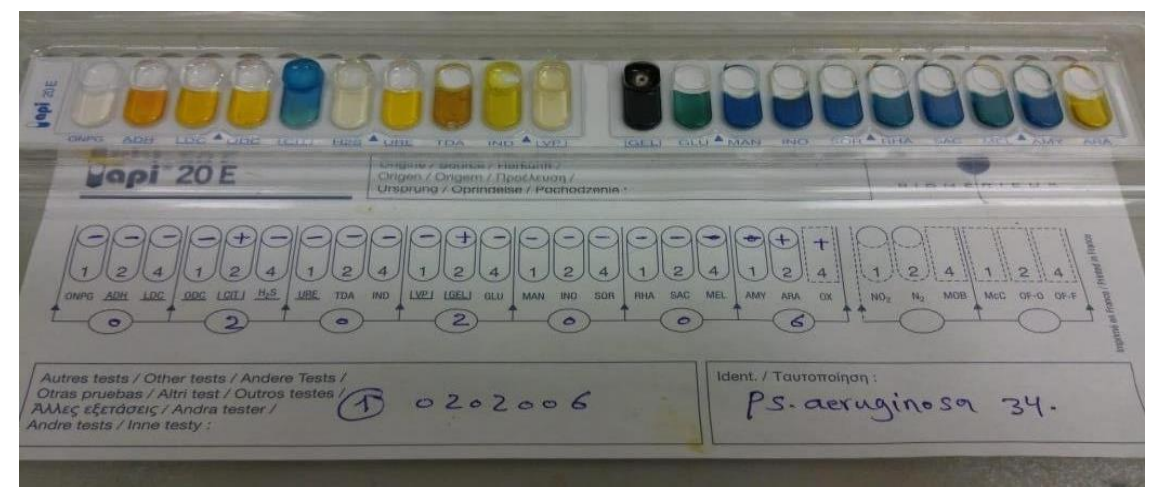

Fig. (1): Results of API 20E of P. aeruginosa

Table (3): Prevalence of $P$. aeruginosa in examined chickens

\begin{tabular}{|c|c|c|c|c|c|c|c|c|c|}
\hline 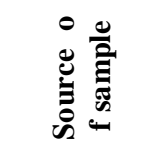 & 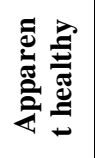 & $b^{\circ}$ & 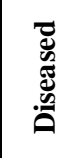 & $b^{\circ}$ & 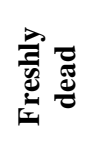 & $b^{\circ}$ & స్ّ & $\therefore$ & 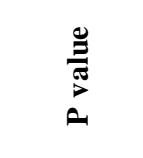 \\
\hline $\begin{array}{c}\text { Broiler } \\
\text { chicks } \\
\text { (1-7 days) }\end{array}$ & 2 & 16.7 & 13 & 29.5 & 4 & 14.3 & 19 & 22.6 & 0.004422 \\
\hline $\begin{array}{c}\text { Broiler } \\
\text { chickens } \\
(1-6 \\
\text { weeks }) \\
\end{array}$ & & & 7 & 17.5 & 2 & 5.4 & 9 & 7.8 & 0.01312 \\
\hline Total & 2 & 3.9 & 20 & 23.8 & 6 & 9.2 & 28 & 14 & \\
\hline$P$ value & 0.15 & & & 797 & & & & & \\
\hline
\end{tabular}




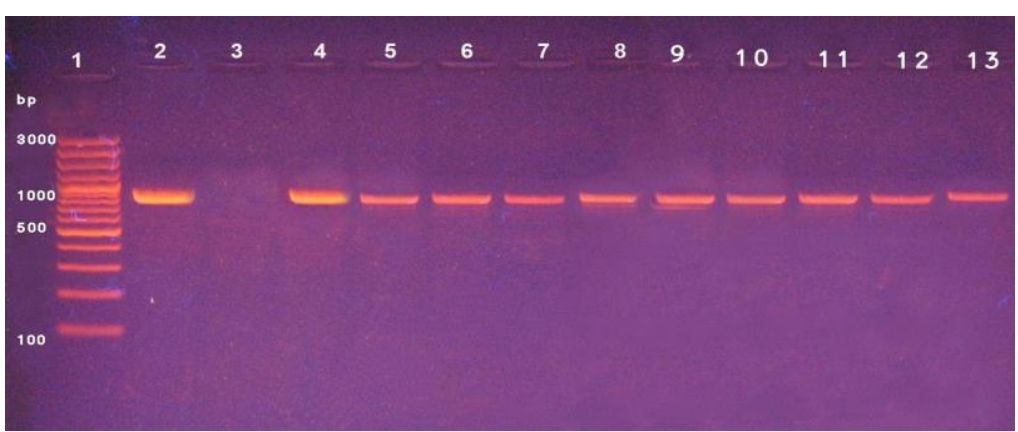

Fig. (2): Agarose gel electrophoresis showing the result of PCR for detection of $16 \mathrm{~S}$ rRNA gene (956 bp) from P. aeruginosa strains Lane 1: 100bp DNA ladder, Lane 2: Control Positive, Lane 3: Control Negative and Lane 4-13: Positive P. aeruginosa isolates for 16S rRNA gene.

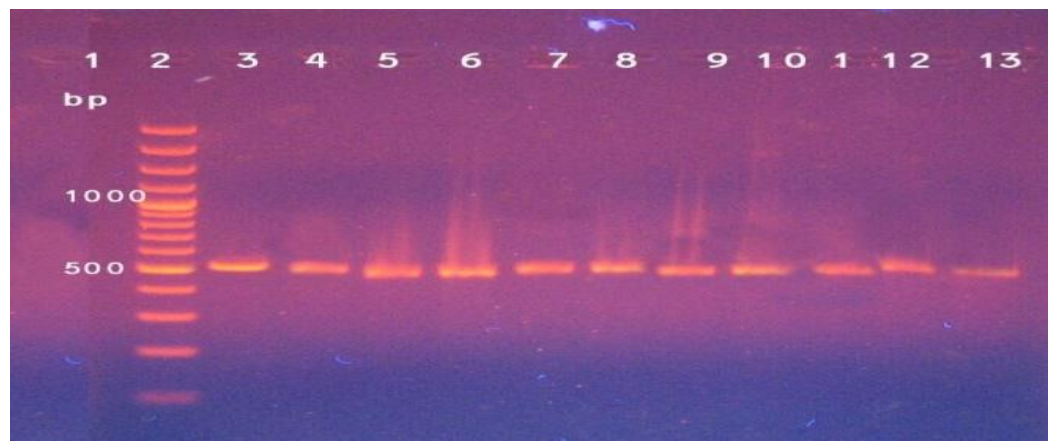

Fig. (3): Agarose gel electrophoresis showing the result of PCR for detection of oprL gene (504 bp) from P. aeruginosa strains

Lane 1: Control Negative, Lane 2: 100bp DNA ladder, Lane 3-12: Positive P. aeruginosa isolates for oprL gene and Lane 13: Control Positive.

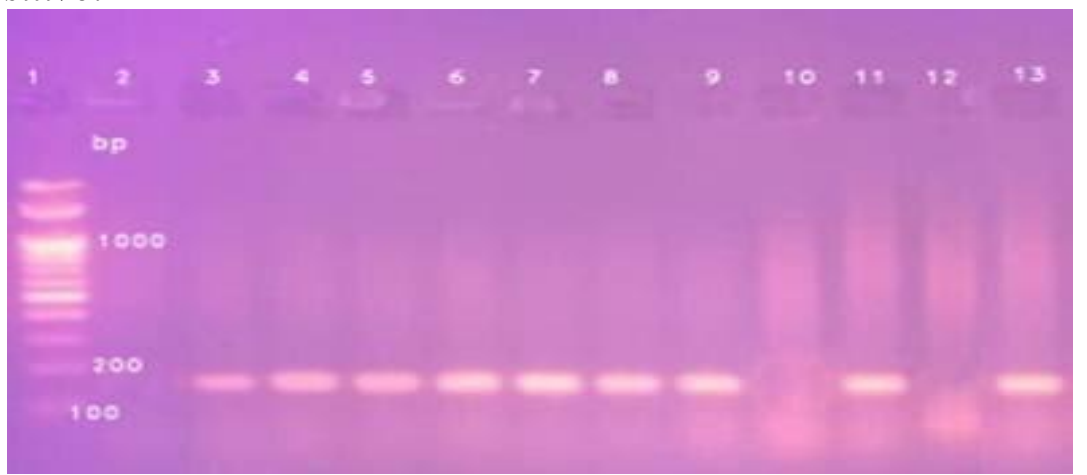

Fig. (4): Agarose gel electrophoresis showing the result of PCR for detection of toxA gene (150 bp) from $P$. aeruginosa strains 
Lane 1: 100bp DNA ladder, Lane 2: Control Negative, Lane 3: Control Positive, Lane 4, 5, 6, 7, 8, 9, 11 \& 13: Positive P. aeruginosa isolates for toxA gene and Lane 10 \& 12: Negative $P$. aeruginosa isolates for toxA gene.

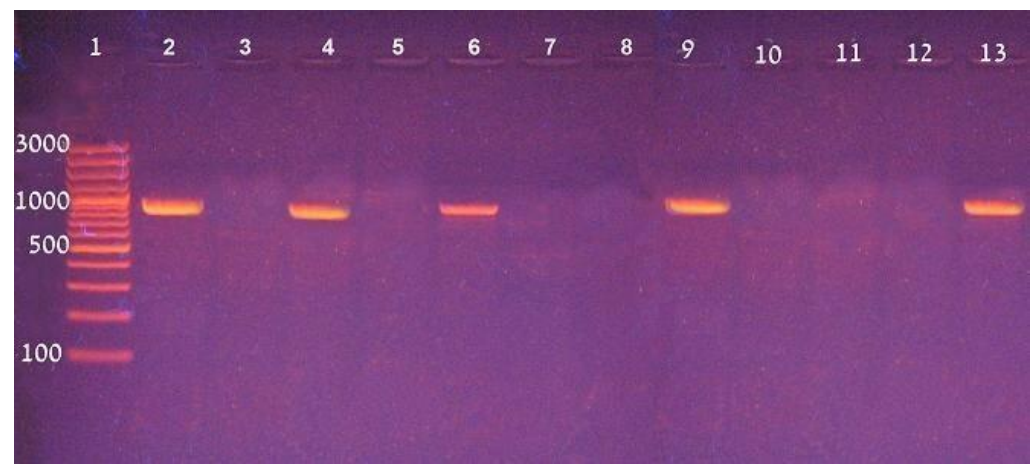

Fig. (5): Agarose gel electrophoresis showing the result of PCR for detection of aprA gene (993 bp) from $P$. aeruginosa strains

Lane 1: 100bp DNA ladder, Lane 2: Control Positive, Lane 3:

Control

Negative, Lane 4, 6, 9 \& 13: Positive P. aeruginosa isolates for aprA gene and Lane 5, 7, 8, 10,11 \& 12: Negative P. aeruginosa isolates for aprAgene.
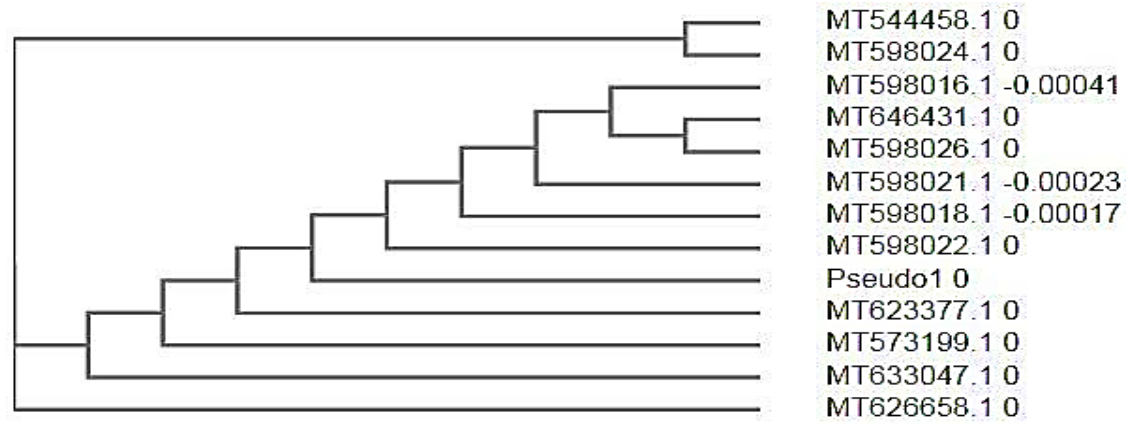

Fig. (6): The phylogenetic analysis of $16 S$ rRNA gene of $P$. aeruginosa

\section{Discussion:}

P. aeruginosa is a problem of economic concern to poultry industry. Therefore, this study tries to illustrate the problem of $P$. aeruginosa in chickens with screening of virulence genes, as well as sequencing that aid in epidemiological relatedness. In this study, 200 broiler chickens of different ages collected from different broilers farms in Suez Canal area were examined for the presence of $P$. 
aeruginosa. The results illustrated in Table (3) showed that the incidence of $P$. aeruginosa in the examined chickens was $14 \%$ (28 out of 200). These results are nearly similar to those recorded by Sidhom (2007) who found that $P$. aeruginosa was recovered from chickens with an incidence of $13.34 \%$ and Enany et al. (1986) and Omran (2012) who recovered $P$. aeruginosa from chickens with an incidence of $12 \%$. In contrast to the present study, lower incidence rates were recorded by Awaad et al. (1981) who isolated $P$. aeruginosa with an incidence of $2.9 \%$ from an outbreak in a broiler flock, and Abd El-Tawab et al. (2014) who isolated 17 isolates of $P$. aeruginosa with an incidence of $4.57 \%$. While, higher incidence rate was recorded by Abd El-Tawabet al. (2018) who isolated $P$. aeruginosa with a percentage of $34 \%$. Concerning the incidence of $P$. aeruginosa in broiler chickens and chicks, results obtained in this study showed that the higher incidence rate was recorded in broiler chicks (1-7 days) $22.6 \%$, in comparis on with old ages (1-6 weeks) $7.8 \%$ as shown in Table (3), these results were supported by Kebede (2010) who proved experimentally that the main cause of high mortalities in unhatched chicken and young chicks, was the infection by $P$. aeruginosa in hatching time. These results are nearly agreeing with those recorded by Mohamed (2004) who isolated $P$. aeruginosa from 85 baby chicks (2-15 days) and 60 broilers (5-8 weeks) with rates of $17.6 \%$ and $3.3 \%$ respectively, Farghaly et al. (2017) who recorded that $P$. aeruginosa isolated from chickens was with a percentage of $5.7 \%(16 / 280)$ and from one-day old chicks $13 \%$ (26/200). On the other hand, these results are not consistent with Hassan (2013) who isolated $P$. aeruginosa from chickens with an incidence of $25.3 \%$ and from one-day-old chicks with an incidence of $8 \%$, Abd El-Tawab et al. (2014) who isolated $P$. aeruginosa from broiler chickens (1-5weeks) with a percentage of $4.85 \%$, meanwhile one isolate of $P$. aeruginosa was isolated from one day old chicks with a percentage of $2.38 \%$. The difference in the prevalence rates may be due to socio-economic factors, climatic changes, health status of birds, food and water supply variation with geographical situation. This study demonstrated also that diseased chickens showed a higher rate with an incidence of $23.8 \%$, in comparison with freshly dead and apparently healthy chickens with incidence rates of $9.2 \%$ and $3.9 \%$, 
respectively as shown in Table (3). These results are nearly similar to those recorded by Farhan (2006) who isolated $P$. aeruginosa from diseased chickens with an incidence of 20.5\%, Satish and Priti (2015) who isolated $P$. aeruginosa from clinically diseased with a rate of 30\%. While, Abd El- Tawab et al. (2014) reported that the incidence rates of $P$. aeruginosa between diseased, freshly dead and apparently healthy chickens were $6.25 \%, 2.38 \%$ and $1.56 \%$, respectively. Concerning the incidence of $P$. aeruginosa according to the site of sampling, $P$. aeruginosa was isolated from liver, intestine, heart blood, lung, yolk sac and cloacal swabs samples but it was not isolated from neither gall bladder nor kidney samples. The yolk sac and cloacal swabs samples gave the highest recovery rates with percentages of $15.5 \%$ and $12.6 \%$, respectively. These results are nearly similar to those recorded by Abd El-Tawab et al. (2014) who reported that cloacal swabs samples gave the highest recovery rate with an incidence of $18.3 \%$. PCR method has been used to provide a specific, rapid, simple, and vastly sensitive discovery of $P$. aeruginosa (Qin et al., 2003). In this study, PCR assured the presence of $P$. aeruginosa DNA in ten isolates with a percentage of $100 \%$ by using specific primers for $P$. aeruginosa (16S rRNA) at 956bp as shown in Fig. (2), these findings were backed by Spilker et al. (2004) who reported that $16 \mathrm{~S}$ rDNA-based PCR assays provided rapid, simple, and reliable identification of $P$. aeruginosa and its differentiation from other phylogenetically closely related Pseudomonas species and it show $100 \%$ sensitivity and specificity. The results obtained in this study are in corroboration with Shahat et al. (2019) who used PCR to inveterate the existence of $P$. aeruginosa DNA in the all seven isolates $(100 \%)$ by using $16 \mathrm{~S}$ rDNA primers at 956 bp. Also, Abdel-Tawabet al. (2016) revealed that $P$. aeruginosa (16S rDNA) gene amplification of 956 bp was observed in the extracted DNA of three isolates out of five tested isolates. However, $\mathbf{A l}$ Dahmoshi et al. (2018) confirmed $P$. aeruginosa using specific primer for $16 \mathrm{~S}$ rDNA gene of $P$. aeruginosa at 956bp with a percentage of $22.8 \%$. Our study was designed for the detection of virulence genes as $o p r \mathrm{~L}$, tox $\mathrm{A}$ and aprA in $P$. aeruginosa isolates by using PCR. The opr $\mathrm{L}$ gene is an outer membrane lipoprotein of $P$. aeruginosa which is responsible for inherent resistance of $P$. aeruginosa to antibiotics and antiseptics. As this protein is found only in this organism, it 
could be a reliable factor for rapid identification of $P$. aeruginosa in clinical samples (Osayande, 2008 and Douraghi et al., 2014). It was found that all ten $P$. aeruginosa isolates showed positive amplification of 504 bp fragment specific for oprL gene (common gene) with a total percentage of $100 \%$ as shown in Fig. (3), it confirmed the existence of $P$. aeruginosa DNA because it considers a specific marker for molecular detection of $P$. aeruginosa. These results are the same obtained by Abd El-Tawab etal. (2014) who used PCR for detection of $o p r \mathrm{~L}$ gene of $P$. aeruginosa in six isolates and all isolates gave a positive amplification of $504 \mathrm{bp}$ fragment specific for the $o p r \mathrm{~L}$ gene of $P$. aeruginosa (species-specific gene), also, Elsayed et al. (2016); Shahat et al. (2019) and Bakheet and Torra (2020) recorded that oprL gene was disclosed in all $P$. aeruginosa isolates with a percentage of $100 \%$. The toxA gene, an inherent genetic sequence located on $P$. aeruginosa chromosome and regulating the synthesis of exotoxin A (exoA), has been widely used as a target for $P$. aeruginosa detection in PCR methods (Khan and Cerniglia, 1994; Qin et al., 2003 and $\mathrm{Xu}$ et al., 2004). The toxA gene was reported in the present study with a percentage of $80 \%$ as shown in Fig. (4), these results were supported by Vasil et al. (1986) and $X u$ et al. (2004) who stated that the toxA gene is produced by the majority of $P$. aeruginosa strains. These results agree with Farghaly et al. (2017) and Bakheet and Torra (2020) who recorded high distribution of toxA gene among $P$. aeruginosa isolates with rates of $80.9 \%$ and $83.3 \%$, respectively. Higher prevalence of toxA gene in $P$. aeruginosa strains $(100 \%)$ was recorded by Sabharwal et al. (2014). Also, Abd El-Tawab et al. (2018); Elmouaden et al. (2019); Shaha et al. (2019); Qian et al. (2020) and Al-Dahmoshi et al. (2018) recorded that toxA (exo A) gene was disclosed in $P$. aeruginosa isolates with percentages of $95 \%, 74.2 \%, 71.4 \%, 60 \%$ and $46.15 \%$, respectively. The aprA gene is an important virulence gene and contributes towards the pathogenicity of $P$. aeruginosa. It was present in four isolates (4 out of 10) with a percentage of $40 \%$ as shown in Fig. (5). This result is in between those recorded by Sabharwal et al. (2014) who recorded that aprA gene was present in a percentage of $16.6 \%$ in $P$. aeruginosa isolates, and Qian et al. (2020) who recorded that the prevalence of aprA gene in $P$. aeruginosa strains was $75 \%$. The analysis of phylogenetic tree revealed identity $(100 \%)$ of $16 \mathrm{~S}$ rRNA 
gene of $P$. aeruginosa isolate in this study to various strains of plant, poultry and other various origins (Dutta et al., 2019 and Maulidia et al., 2021). This epidemiological relatedness revealed that plants may be considered a source of infection.

\section{References:}

Abd El- Tawab, A. A., El-Hofy, F. I., Khater, D. F. and Al-Adl, M. M. (2014): PCR detection and gene sequence of Pseudomonas aeruginosa isolated from broiler chickens. BVMJ., 27(2): 449-455.

Abdel-Tawab, A. A., Nasef, S. A. and Ibrahim, O. A. (2016): Bacteriological and molecular studies on bacteria causing omphalitis in chicks with regard to disinfectant resistance. Global Veterinaria, 17(6): 539-545.

Abd El- Tawab, A. A., El-Hofy, F. I., Khater, D. F. and Al-Adl, M. M. (2018): Virulence, resistance genes detection and sequencing of gyrA gene of Pseudomonas aeruginosa isolated from chickens and human in Egypt. Nat. Sci.,16(2): 32-39.

Adams, M. R. and Moss, M. O. (2008): Food Microbiology. $3^{\text {rd }}$ edition. The Royal Society of Chemistry, UK.

Al-Dahmoshi, H. O. M., AlKhafaji, N. S., Jeyad, A. A., Share ef, H. K. and Al-Jebori,
R. F. (2018): Molecular detection of some virulence traits among Pseudomonas aeruginosa isolates, Hilla-Iraq. Biomed. Pharmacol. J., 11(2): 835-842.

Arnaut-Rollier, I., Vauterin , L., De Vos, P., Massart, D. L., Devriese, L. A., De Zutter, L. and Van Hoof, J. (1999): A numerical taxonomic study of the Pseudomonas flora isolated from poultry meat. Journal of Applied Microbiology, 87: 1528.

Awaad, M. H., Youssef, Y. I., Saad, F. E. and Sarakbi, T. M. B. (1981): Study on $P$. aeruginose in chickens. Vet. Med. J. of Cairo Univ., 29: 135143.

Bakheet, A. A. and Torra, D. E. (2020): Detection of Pseudomonas aeruginosa in dead chicken embryo with reference to pathological changes and virulence genes. Alexandria Journal of Veterinary Sciences, 65(1): 81-89.

Barnes, H. J. (1997): Other bacterial diseases: Pseudomonas. In Diseases of Poultry, edited by Calnek, B. W., John Barnes, H., Beard, C. W., Mcdougald, L. R. and Saif, Y. M., (10th edition), 4: 291-292.

Deschaght, P., Van Daele, S., De Baets, F. and Vane echoutte, M. (2011): PCR and the detection of Pseudomonas 
aeruginosa in respiratory samples of $\mathrm{CF}$ patients. A literature review. J. Cyst. Fibros.,10 (5): 293-297.

Douraghi, M., Ghasemi, F., Dallal, M. M., Rahbar, M. and Rahimiforoushani, A. (2014): Molecular identification of Pseudomonas aeruginosa recovered from cystic fibrosis patients. J. Prev. Med. Hyg., 55(2): 50-53.

Dutta, S., Sarkar, A. and Dutta, S. (2019): Characterization of Pseudomonas aeruginosa MCC 3198 and its potential for growth promotion of seedlings of the medicinal plant Celosia cristata L. Int. J. Curr. Microbiol. App. Sci., 8(4): 985-997.

Elmouaden, C., Laglaoui, A., Ennanei, L., Bakkali, M. and Abid, M. (2019): Virulence genes and antibiotic resistance of Pseudomonas aeruginosa isolated from patients in the Northwestern of Morocco. J. Infect. Dev. Ctries., 13(10): 892898.

Elsayed, M. S. A., Ammar, A. M., Al shehri, Z. S., Abd-El Rahman, H. and AbdEl Rahman, N. A. (2016): Virulence repertoire of Pseudomonas aeruginosa from some poultry farms with detection of resistance to various antimicrobials and plant extracts. Cell. Mol. Biol., 62(1): 124.
Enany, M., El-Kenawy, A. and Abd El-Galil, Y. (1986): Study on Pseudomonas aeruginosa infection in Sharkia Governorate. Zagazig. Vet. J., 14: 104-111.

Farghaly, E. M., Roshdy, H., Bakheet, A. A., Abd El-Hafez, A. S. and Badr, H. (2017): Advanced studies on Pseudomonas aeruginosa infection in chicken. Animal Health Research Journal, 5(4): 207-217.

Farhan, H. E. (2006): Bacteriological and histopathological studies on Pseudomonas aeruginosa infection in chickens. M. V. Sc. Thesis (Microbiology), Fac. Vet. Med., Suez Canal Univ.

Fick, R. (1993): Pseudomonas aeruginosa-the Microbial Hyena and Its Role in Disease: An Introduciton. Pseudomonas aeruginosa: The Opportunist. pp:1-6.

Franzetti, L. and Scarpellini, M. (2007): Characterisation of Pseudomonas spp. isolated from foods. Ann. Microbiol., 57(1): 39-47.

Gellatly, S. L. and Hancock, R. E. (2013): Pseudomonas aeruginosa: New insights into pathogenesis and host defenses. Pathog. Dis., 67(3): 159-173.

Greenwood, P. E. and Nikulin, M. S. (1996): A guide to chi- 
squared testing. New York: Wiley. ISBN 0-471-55779-X.

Hassan, H. M. (2013): Characterization

Pseudomonas isolated from different pathological lesions in chickens. M. V. Sc. Thesis (Microbiology), Fac. Vet. Med., Beni-Suef Univ.

Hoge, R., Pelzer, A., Rosenau, F. et al. (2010): Weapons of a pathogen: proteases and their role in virulence of Pseudomonas aeruginosa. In: Mendez-Vilas A (ed). Current Research, Technology and Education Topics in Applied Microbiology and Microbial Biotechnology. Badajoz: Formatex Research Center, 383395.

Jay, J. M., Loessner, M. J. and Golden, D. A. (2005): Modern food microbiology. 7th edition. Springer Science, USA.

Kebede, F. (2010): Pseudomonas infection in chickens. Journal of Veterinary Medicine and Animal Health, 2(4): 55-58.

Khan, A. A. and Cerniglia, C. E. (1994): Detection of $P$. aeruginosa from clinical and environmental samples by amplification of the exotoxin A gene using PCR. Appl. Environ. Microbiol., 60(10): 3739-3745.
Khattab, M. A., Nour, M. S. and ElSheshtawy, N. M. (2015): Genetic identification of Pseudomonas aeruginosa virulence genes among different isolates. $\mathbf{J}$. Microb. Biochem. Technol., 7(5): 274-277.

Maulidia, V., Sriwati, R., Soesanto, L. et al. (2021): Endophytic bacteria isolated from higher plant in Aceh, Indonesia, and their chemical compounds activity against Fusarium oxysporum f. sp. lycopersici. Egypt J Biol Pest Control, 31(31).

Mohamed, H-A. A-E. (2004): Some studies on Pseudomonas species in chicken embryos and broilers in Assiut Governorate. Ass. Univ. Bull. Environ. Res., 7(1): 23-31.

Omran, G. A. (2012): Characterization of Pseudomonas spp. of avian origin. M. V. Sc. Thesis (Microbiology), Fac. Vet. Med., Cairo Univ.

Osayande, J. (2008): Easy identification of difficult-totype Pseudomonas aeruginosa clinical and environmental isolates. Internet J. Microbiol., 7(2): 45-51.

Qian, Z., Hui, P., Han, L., Ling-Zhi, Y., Bo-Shun, Z., Jie, Z., Wan-Li, G., Nan, W., ShiJin, J. and Zhi-Jing, X. (2020): Serotypes and virulence genes of 
Pseudomonas aeruginosa isolated from mink and its

pathogenicity in mink. Microb. Pathog., 139: 103904.

Qin, X., Eme rs on, J., Stapp, J., Stapp, L., Abe, P. and Burns, J. L. (2003): Use of real-time PCR with multiple targets to identify Pseudomonas aeruginosa and other nonfermenting gram-negative bacilli from patients with cystic fibrosis. J. Clin. Microbiol., 41(9): 4312-4317.

Quinn, P. J., Markey, B. K., Carter, M. E., Donnelly, W. J. and Leonard, F. C. (2002): Veterinary Microbiology and Microbial Disease. Blackwell scientific publications, Oxford, London.

Saad, Z. A., Nasef, S. A., Elhariri, M., Elhelw, R. and Ezzeldeen, N. (2017): Resistance patterns associated with bacterial pathogens causing omphalitis in baby chicks. Journal of Bioscience Research, 14(4): 845-851.

Sabharwal, N., Dhall, S., Chhibber, S. and Harjai, $K$. (2014): Molecular detection of virulence genes as markers in Pseudomonas aeruginosa isolated from urinary tract infections. Int. J. Mol. Epidemiol. Genet., 5(3): 125134.
Salman, A. (2015): ToxA gene as a chromosomal marker for rapid identification of Otitis media Pseudomonas aeruginosa. Int'l Journal of Advances in Chemical Engg., \& Biological Sciences (IJACEBS) Vol. 2, Issue1.

Satish, S. and Priti, M. (2015): Pseudomonas aeruginosa infection in broiler chicks in Jabalpur. International J. Ext. Res., 6: 37-39.

Shahat, H. S., Mohamed, H. M. A., Abd Al-Azeem, M. W. and Nasef, S. A. (2019): Molecular detection of some virulence genes in Pseudomonas aeruginosa isolated from chicken embryos and broilers with regard to disinfectant resistance. SVU- IJVS., 2(2): 5270.

Sidhom, S. S. (2007): Molecular studies on resistant genes of Pseudomonas aeruginosa. M. V. Sc. Thesis (Microbiology), Fac. Vet. Med., Cairo Univ.

Spilker, T., Coenye, T., Vandamme, P. and LiPuma, J. J. (2004): PCR-based assay for differentiation of Pseudomonas aeruginosa from other Pseudomonas species recovered from cystic fibrosis patients. J. Clin. Microbiol., 42(5): 20742079.

Van Delden, C. and Iglewski, B. H. (1998): Cell-to-cell signaling and Pseudomonas 
aeruginosa infections. Emerg. Infect. Dis., 4(4):551-560.

Vasil, M. L., Chamberlain, C. and Grant, C. C. (1986): Molecular studies of Pseudomonas exotoxin A gene. Infect. Immun., 52(2): 538-548.

Woo, P. C. Y., Lau, S. K. P., Teng, J. L. L., Tse, H. and Yuen, K.Y. (2008): Then and now: use of $16 \mathrm{~S}$ rDNA gene sequencing for bacterial identification and discovery of novel bacteria in clinical microbiology laboratories. Clin. Microbiol. Infect., 14(10): 908934.

Xu, J., Moore, J. E., Murphy, P. G., Millar, B. C. and Elborn, J. S. (2004): Early detection of Pseudomonas aeruginosacomparison of conventional versus molecular (PCR) detection directly from adult patients with cystic fibrosis (CF). Ann.Clin.Microbiol. Antimicrob., 3:21.

\section{توصيف جزيئي وتحليل جيني للسودوموناس ارجينوزا المعزولة من دجاج التسمين \\ 'سهاسامى الصده، ' أبو الخير ابراهيم عيسوي، بريهام مختار الطر ابيلي، بأحمدرفعت

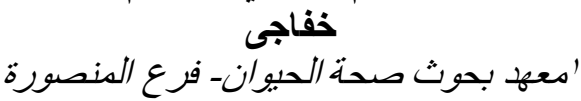 \\ 'آقسم البكتريا و المناعه والفطريات ـ كلبة الطب البيطرى ــ جامعة قناة السوبيس

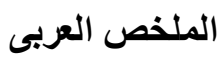

يعتبر السودوموناس ارجينوزا ممرض انتهازي و يسبب مشاكل خطيره في مز ارئ ارع التسمين

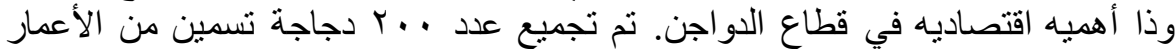

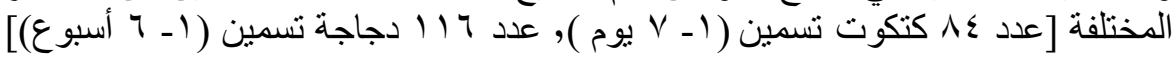

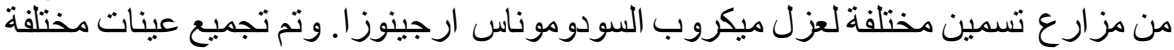

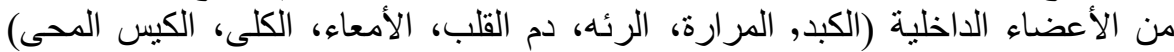

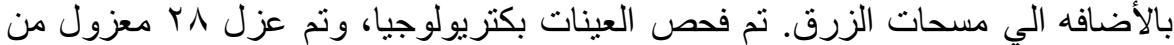

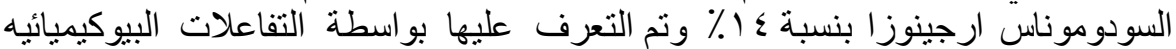

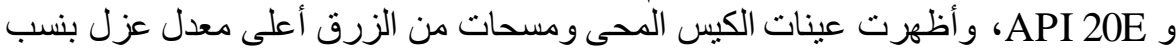

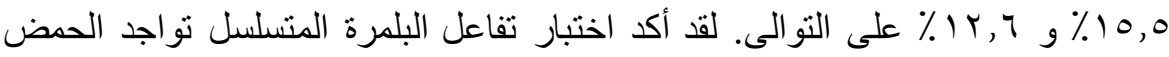

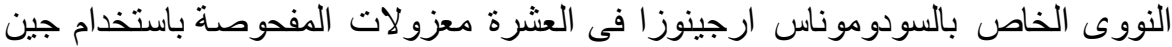
16S rRNA

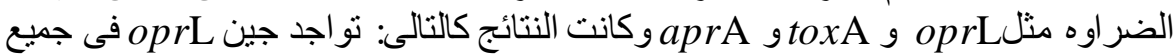

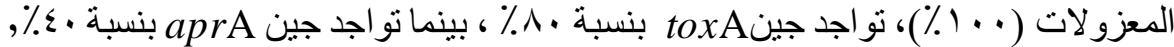

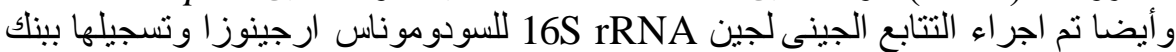

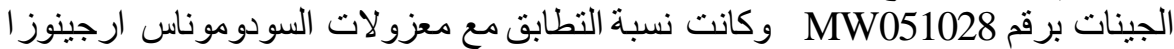

